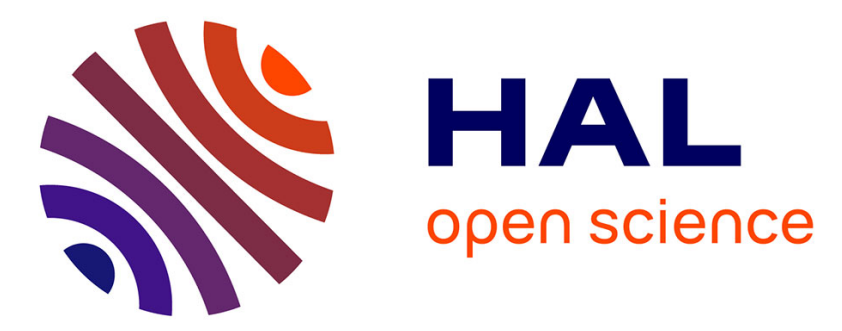

\title{
Mortality gradient across the labour market core-periphery structure: a 13-year mortality follow-up study in north-eastern France
}

M Khlat, S Legleye, B Falissard, N Chau, Jean-François Ravaud

\section{- To cite this version:}

M Khlat, S Legleye, B Falissard, N Chau, Jean-François Ravaud. Mortality gradient across the labour market core-periphery structure: a 13-year mortality follow-up study in north-eastern France. International Archives of Occupational and Environmental Health, 2014, 87 (7), pp.725-733. 10.1007/s00420013-0915-4 . hal-03479107

\section{HAL Id: hal-03479107 \\ https://cnrs.hal.science/hal-03479107}

Submitted on 24 Jan 2022

HAL is a multi-disciplinary open access archive for the deposit and dissemination of scientific research documents, whether they are published or not. The documents may come from teaching and research institutions in France or abroad, or from public or private research centers.
L'archive ouverte pluridisciplinaire HAL, est destinée au dépôt et à la diffusion de documents scientifiques de niveau recherche, publiés ou non, émanant des établissements d'enseignement et de recherche français ou étrangers, des laboratoires publics ou privés.

\section{(ㄷ)(1) $\$$}

Distributed under a Creative Commons Attribution - NonCommerciall 4.0 International 


\title{
Mortality gradient across the labour market core-periphery structure: a 13-year mortality follow-up study in north-eastern France
}

\author{
M. Khlat $\cdot$ S. Legleye $\cdot$ B. Falissard $\cdot$ \\ N. Chau $\cdot$ the Lorhandicap group
}

\begin{abstract}
Purpose This study explores mortality related to temporary employment, about which very little is known to date. Methods In 1996, a health survey was carried out in the French region of Lorraine, and all members of 8,000 randomly chosen households were followed up for mortality over a 13-year period. Mortality of subjects in relation to their employment situation at baseline was analysed using a Cox survival regression.

Results In comparison with permanent workers, for unemployed men, we found age and occupation-adjusted hazard ratios (HR) of 4.1 for all-causes of death and 3.9 for non-violent causes, and for male temporary workers a HR of 2.2 for both all-causes and non-violent causes of death. Bad health, tobacco smoking and alcohol misuse explained $17 \%$ of the excess risk for the unemployed and $41 \%$ of that for temporary workers.

Conclusion The observation of large mortality inequalities across the labour market core-periphery structure has important policy implications, particularly in terms of prevention focused on unhealthy behaviours among male unemployed and temporary workers.
\end{abstract}

\author{
M. Khlat $(\bowtie) \cdot$ S. Legleye \\ Institut National d'Etudes Démographiques, 133 Boulevard \\ Davout, 75980 Paris Cedex 20, France \\ e-mail: khlat@ined.fr \\ S. Legleye $\cdot$ B. Falissard $\cdot$ N. Chau \\ INSERM, U669, 75014 Paris, France \\ S. Legleye $\cdot$ B. Falissard $\cdot$ N. Chau \\ Univ Paris-Sud, Univ Paris Descartes, UMR-S0669, \\ Paris, France \\ B. Falissard \\ Assistance Publique-Hôpitaux de Paris, 94804 Villejuif, France
}

Keywords Mortality - Inequalities · Unemployment · Temporary work · Precarious work · Flexibility · Health behaviours

\section{Introduction}

The flexible labour market is typically segmented: the centre or core comprises individuals employed on a permanent basis or with no fixed term, and it is surrounded by a band of individuals in various kinds of restricted-term employment. In past decades, there has been a re-composition of the work force, with a steady development of the peripheral segments to the detriment of the core of secure employments. In both Europe and the USA, the number of individuals in temporary employment is now exceeding the number of unemployed, and the different forms of flexible jobs have much in common with unemployment in terms of social and economic disadvantages (Benach et al. 2002; Virtanen et al. 2005).

The excess morbidity and mortality among men and women having experienced unemployment has been extensively described in the literature (Bartley et al. 1999; Roelfs et al. 2011). However, there is no agreement on the consequences of flexible work on health, since available studies are not conclusive. The experience of job insecurity has been associated with psychological morbidity but not with physical morbidity (Quesnel-Vallée et al. 2010; Virtanen et al. 2003, 2005; Waenerlund et al. 2011), and, apart from studies in Finland (Kivimäki et al. 2003; Nätti et al. 2009), there is little evidence of an association between job insecurity and premature mortality.

Yet there are several pathways through which temporary work might have adverse health consequences. Temporary workers are more exposed than permanent ones to work 
strain and physical hardship (painful and tiring positions, intense noise and repetitive movements) and to hazardous work conditions, because they often have limited on-thejob training and may feel more constrained by their insecure position to complain about working conditions and risks (Benach et al. 2000, 2002). In addition, studies from different countries suggest that they are more prone to tobacco smoking and alcohol abuse (De Cuyper et al. 2008; Jung et al. 2013; Kivimäki et al. 2003; Legleye et al. 2011). Given their general pattern of social and material deprivation, temporary workers are also less likely to be properly treated (Iezzoni and O'Day 2006; van Beljouwe et al. 2010), and therefore, special attention should be given to their healthcare needs.

Selection processes may, however, distort the picture in unpredictable ways. The "healthy worker effect" to which temporary workers are subject at selection into employment is one candidate, and this pattern is compounded by poor health hindering transition from temporary employment to permanent employment and favouring transition from temporary employment to unemployment (Bardasi and Francesconi 2004; De Cuyper et al. 2009; Virtanen et al. 2002, 2006). Lastly, poor health may lead to disability, which in turn may accelerate exit from the labour market and transition to inactivity.

The purpose of this study was to investigate mortality inequalities in relation to the structure of the labour force from core to periphery. Our data originate from the Lorraine region in north-eastern France, which has been particularly exposed to labour market hardship during the past decades. In France, the unemployment rate has fluctuated around $10 \%$ since the mid-1980s, and limited-term contracts have constantly been on the rise, reaching $12.6 \%$ of salaried workers in 2009 (INSEE 2011). The Lorraine region, a leading industrial region after the Second World War, has undergone massive de-industrialization and tertiarization over the last 50 years, with a significant growth of unemployment and temporary employment (Thirion and Schmitt 2010). Currently, Lorraine is particularly disadvantaged in terms of unemployment and poverty compared to the other French regions.

This study uses a unique epidemiological mortality follow-up survey, the Lorhandicap health survey, which was implemented in Lorraine in 1996 and comprised 8,000 randomly chosen households, of which all members were carefully followed up for mortality over a 13-year period, i.e. until 2008. Our research questions were as follows: (1) Is the mortality of temporary workers higher than that of workers with permanent employment, and how does it compare with that of the unemployed, adjusting for age and occupational group? (2) Are the mortality differences, if any, explained by health status and health-related behaviours at baseline?

\section{Materials and methods}

\section{Procedure}

Several studies based on the Lorhandicap survey data have already been published (Baumann et al. 2007; Chau et al. 2009; Lemogne et al. 2012). The initial sample consisted of subjects aged 15 years or more living in 1996 in 8,000 randomly selected households in the Lorraine region of north-eastern France (2.3 million inhabitants), representing $1 / 100$ of the population. The investigation was approved by the Commission Nationale de l'Informatique et des Libertés (national review board), and a written informed consent was obtained from the respondents.

\section{Measures}

All measures were collected using the survey questionnaire administered at the start of the study in 1996. Occupation was chosen as an indicator of adult socioeconomic status, and employment situation was categorized into permanent employment (paid employment with unlimited duration, i.e. civil servants, workers with indefinite-term contracts and self-employed), temporary employment (project employees, workers "on-call" and workers from temporary labour agencies) and unemployment. Subjects who were not in the labour force at study baseline were excluded (retirees, students, at-home mothers and other non-working people not looking for employment).

Five occupational categories were considered, following the International Classification of Occupation (ISCO) (Kivimäki et al. 2003): professionals/managers (reference category), associate professionals/technicians, service workers/clerks, manual workers and others. We used selfreported health, with a categorization into good ("very good" and "good"), average ("average"), and poor or bad (grouping "mediocre" and "bad"). Behavioural factors included smoking status (smoker, ex-smoker or non-smoker), and "alcohol misuse" which was measured using the French version of the Cut/Annoyed/Guilty/Eye-opener (CAGE) questionnaire (Beresford et al. 1990) and defined by at least two positive responses to four items: consumption considered excessive by the subject, consumption considered excessive by people around the subject, subject wishes to reduce consumption and consumption on waking.

\section{Follow-up}

The cohort was followed up for mortality from 1st July 1996 to 31st December 2008 (12.5 years). The vital status of all subjects was ascertained from the national computerized database listing all deceased subjects in France from 1978 , by contacting the registry offices of the birth places 
for people born in France and by contacting the registry office for foreign-born French citizens (Ministry of Foreign Affairs). Causes of death were coded by the French national cause-of-death registry (INSERM) using the current revisions of the International Classification of Diseases. Violent mortality corresponds to codes E800.0-E999 (8th or 9th revision) or V01.0-Y89.9 (10th revision) and comprises suicides, homicides and accidental deaths. Nonviolent deaths comprise all other deaths.

\section{Statistical analysis}

The study aimed to explore the 13-year (1996-2008) subsequent mortality of subjects who were temporary workers at baseline and to compare it to that of unemployed and permanent workers. The duration of follow-up for each subject was from 1 July 1996 to either the date of death or 31 December 2008 for those still alive at the end of followup. Cox regression models were used to examine the associations of employment status with all-cause mortality, non-violent mortality and violent mortality.

To assess the roles played by self-reported health and behavioural risk factors in all-cause mortality, three Cox regression models were performed: a basic model (model 1) including age and occupation; then self-reported health was added to model 1 (model 2); and finally, behavioural risk factors were added to model 2 (model 3). The contributions of self-reported health and those of behavioural risk factors were estimated by the changes in the HRs, derived from the formulas: $\left(\mathrm{HR}_{\text {model }} 1-\mathrm{HR}_{\text {model }}{ }_{2}\right) /$ $\left(\mathrm{HR}_{\text {model } 1}-1\right)$ and $\left(\mathrm{HR}_{\text {model } 1}-\mathrm{HR}_{\text {model } 3}\right) /\left(\mathrm{HR}_{\text {model } 1}-1\right)$, respectively. The proportional hazard assumption was evaluated from Schoenfeld residuals for the global model and for each covariate. The statistical analyses were performed using STATA software (Stata, College Station, TX, USA).

\section{Sample}

Of the 8,000 households included in the sample, dispatches to $193(2 \%)$ were lost (due to addressing error or death). Of the 7,807 households contacted, 3,460 (44.3\%) participated (all eligible members of the family took part in $86 \%$ of these). In total, 6,234 subjects filled in a questionnaire, including 34 failing to provide gender or age data, leaving a population of 6,200 subjects. The composition of the initial sample was found to be close to that of the census population ("Appendix").

During mortality follow-up, 157 subjects $(2.5 \%)$ were lost and excluded, resulting in a study population of 6,043 participants. Only the subjects who were either working or unemployed and aged between 30 and 64 years at baseline (1st July 1996) were retained for this study, i.e. 2,500 subjects, 1,402 men and 1,098 women. In total, 95 deaths (66 men and 29 women) occurred.

\section{Results}

The subjects experiencing temporary employment had lower occupational categories, poorer self-reported health, greater exposure to behavioural risk factors (for men) and higher general and cause-specific mortality than permanent workers, but a somewhat more favourable profile than the unemployed (Table 1). Hazard ratios for mortality from all-causes, adjusted for age and occupation, differed between men and women, and a significantly elevated hazard ratio was found for temporary male workers $(2.2$ times higher risk, $p<0.05$ ), and, as expected, for unemployed males (4.1 times higher risk, $p<0.001$ ), compared to permanent workers (Table 2). With regard to non-violent mortality, the analyses highlighted a significant disadvantage among men for both temporary workers and unemployed (2.2 times higher risk, $p<0.05$ and 3.9 times higher risk $p<0.01$, respectively). After subdividing nonviolent mortality into mortality from cancers and mortality from cardiovascular diseases, the gap remained pronounced and significant for cardiovascular mortality (3.6 and 5.5 times higher risk, $p<0.05$, respectively), while the estimates for cancer mortality, although elevated (2.3 and $2.9)$, did not reach significance $(p<0.10)$. For violent mortality, no significant hazard ratio was found for temporary workers, while the estimates were elevated for unemployed men $(7.2$, close to significance, $p<0.10)$ and significantly elevated for unemployed women (11.2, $p<0.05$ ).

Using nested models, we found that after inclusion of health in a first stage, and health-related behaviours in a second stage, the excess risks of death found for men were substantially reduced by 35 and $41 \%$ for temporary workers and by 20 and $17 \%$ for unemployed, remaining significant only for the latter $(3.6, p<0.01)$ (Table 3$)$. Further analyses failed to demonstrate a major role of these factors in explaining mortality from cardiovascular diseases for either the temporary workers or the unemployed. Conversely, the elevated (but non-significant) estimates for cancer mortality were substantially reduced after adjustment for both temporary workers and the unemployed.

\section{Discussion}

The mortality of non-permanent employees has received very little attention to date, and the differences that we have uncovered are impressive, with increasing levels when shifting from permanent employment at baseline to 
Table 1 Sample description: distribution percentages for the explanatory variables in the different employment groups (age 30-64 years)

\begin{tabular}{|c|c|c|c|c|c|c|c|c|}
\hline & \multicolumn{4}{|l|}{ Men } & \multicolumn{4}{|l|}{ Women } \\
\hline & $\begin{array}{l}\text { Permanent } \\
\text { workers }\end{array}$ & $\begin{array}{l}\text { Temporary } \\
\text { workers }\end{array}$ & Unemployed & $\begin{array}{l}\text { Pearson } \mathrm{chi}^{2} \text { or } \\
\text { Fisher test } \\
(p \text { value })\end{array}$ & $\begin{array}{l}\text { Permanent } \\
\text { workers }\end{array}$ & $\begin{array}{l}\text { Temporary } \\
\text { workers }\end{array}$ & Unemployed & $\begin{array}{l}\text { Pearson } \mathrm{chi}^{2} \text { or } \\
\text { Fisher test } \\
(p \text { value })\end{array}$ \\
\hline $\begin{array}{l}\text { Total number of } \\
\text { individuals }\end{array}$ & 1,231 & 130 & 41 & & 858 & 166 & 74 & \\
\hline $\begin{array}{c}\text { Number of person- } \\
\text { years until } 2008\end{array}$ & 15,295 & 1,569 & 459 & & 10,728 & 2,072 & 907 & \\
\hline \multicolumn{9}{|c|}{ Sociodemographic characteristics } \\
\hline \multicolumn{9}{|l|}{ Age (years) } \\
\hline Mean (SD) & $42.0(7.9)$ & $42.9(9.1)$ & $46.4(10.0)$ & 0.0021 & $42.0(8.0)$ & $43.6(10.7)$ & $44.8(9.4)$ & 0.0045 \\
\hline Range & $30-64$ & $30-62$ & $30-64$ & & $30-64$ & $30-64$ & $30-63$ & \\
\hline Occupation & & & & $<0.001$ & & & & $<0.001$ \\
\hline Managers & 22 & 17 & 20 & & 17 & 12 & 4 & \\
\hline $\begin{array}{l}\text { Intermediate } \\
\text { professionals, } \\
\text { technicians }\end{array}$ & 21 & 15 & 15 & & 9 & 4 & 1 & \\
\hline $\begin{array}{l}\text { Service workers, } \\
\text { clerks }\end{array}$ & 19 & 22 & 5 & & 57 & 51 & 54 & \\
\hline Manual workers & 34 & 32 & 46 & & 11 & 10 & 26 & \\
\hline Others & 4 & 14 & 15 & & 7 & 23 & 15 & \\
\hline \multicolumn{9}{|l|}{ Risk factors } \\
\hline \multicolumn{9}{|c|}{ Health-related behaviours } \\
\hline Smoking & & & & 0.056 & & & & 0.781 \\
\hline Non-smoker & 28 & 21 & 12 & & 48 & 49 & 42 & \\
\hline Ex-smoker & 36 & 43 & 44 & & 26 & 25 & 26 & \\
\hline Smoker & 36 & 36 & 44 & & 26 & 25 & 32 & \\
\hline Alcohol abuse & 13 & 22 & 15 & 0.027 & 4 & 4 & 5 & 0.797 \\
\hline \multicolumn{9}{|c|}{ Health profile (self-reported health) } \\
\hline Good & 65 & 51 & 49 & $<0.001$ & 66 & 60 & 53 & 0.009 \\
\hline Average & 30 & 35 & 34 & & 29 & 33 & 34 & \\
\hline Poor or bad & 4 & 14 & 17 & & 5 & 7 & 14 & \\
\hline \multicolumn{9}{|c|}{ Mortality (crude death rate per 1,000 person-years) } \\
\hline From all-causes & 3.0 & 7.6 & 17.4 & & 1.8 & 2.4 & 5.5 & \\
\hline Non-violent deaths & 2.6 & 7.0 & 15.3 & & 1.6 & 2.4 & 3.3 & \\
\hline Cancers & 1.5 & 3.8 & 6.5 & & 1.1 & 1.0 & 3.3 & \\
\hline $\begin{array}{l}\text { Cardiovascular } \\
\text { diseases }\end{array}$ & 0.5 & 2.5 & 4.4 & & 0.2 & 0.5 & 0 & \\
\hline Other causes & 0.6 & 1.3 & 4.4 & & 0.3 & 0.9 & 0 & \\
\hline Violent deaths & 0.4 & 0.6 & 2.2 & & 0.2 & 0 & 2.2 & \\
\hline
\end{tabular}

temporary employment (2.2 times higher risk) and to unemployment (4.1 times higher risk). Temporary employment and unemployment are in most cases transient situations in employment trajectories, and a study covering the 1990s indicates that two-thirds of the temporary workers reached permanent employment within 3 years (Junod 2006). Our findings are all the more striking, as changes during the course of follow-up are bound to dilute differences across groups.
The large mortality inequalities associated with the situation at baseline are likely to reflect both direct and indirect selection into precarious employment and longterm influence of the socioeconomic disadvantage attached to that position on health. In France, it has been demonstrated that the destabilization of workers into flexible employment was not generalized but rather concentrated on the less stable segment of the population (Petit 2006). In support of this hypothesis, in this study, we have found 
Table 2 Association between employment status and mortality by cause: age and occupation-adjusted hazard ratios (HRs and $95 \%$ confidence intervals)

\begin{tabular}{|c|c|c|c|c|c|c|}
\hline & \multicolumn{3}{|l|}{ Men } & \multicolumn{3}{|l|}{ Women } \\
\hline & $\begin{array}{l}\text { Permanent } \\
\text { workers }\end{array}$ & $\begin{array}{l}\text { Temporary } \\
\text { workers }\end{array}$ & Unemployed & $\begin{array}{l}\text { Permanent } \\
\text { workers }\end{array}$ & $\begin{array}{l}\text { Temporary } \\
\text { workers }\end{array}$ & Unemployed \\
\hline Number of subjects & 1,231 & 130 & 41 & 858 & 166 & 74 \\
\hline Number of person-years & 15,295 & 1,569 & 459 & 10,728 & 2,072 & 907 \\
\hline Mortality from all-causes & 1.00 & 2.21* (1.16-4.24) & $\mathbf{4 . 0 9} * * *(1.85-9.01)$ & 1.00 & $1.28(0.45-3.62)$ & $2.69(0.97-7.43)$ \\
\hline Non-violent mortality & 1.00 & $\mathbf{2 . 2 2} *(1.12-4.40)$ & $\mathbf{3 . 8 7} * *(1.66-9.03)$ & 1.00 & $1.33(0.46-3.88)$ & $1.80(0.51-6.32)$ \\
\hline Cancers & 1.00 & $2.25(0.90-5.65)$ & $2.89(0.82-10.18)$ & 1.00 & $0.88(0.18-4.21)$ & $2.79(0.76-10.30)$ \\
\hline Cardiovascular diseases & 1.00 & 3.56* $(1.02-12.44)$ & $\mathbf{5 . 4 6}^{*}(1.07-27.84)$ & 1.00 & $2.72(0.21-34.95)$ & 0 \\
\hline Violent mortality & 1.00 & $1.84(0.22-15.44)$ & $7.20(0.82-63.34)$ & 1.00 & 0 & 11.16* $(1.48-84.37)$ \\
\hline
\end{tabular}

Significant estimates are in bold $* p<0.05 ; * * p<0.01 ; * * * p<0.001$

Table 3 Association between employment status and mortality for men: additional adjustment for health, tobacco and alcohol: hazard ratios (HRs and $95 \%$ confidence intervals, reference category: permanent workers)

\begin{tabular}{|c|c|c|c|c|}
\hline \multirow[t]{2}{*}{ Model } & \multicolumn{2}{|c|}{$\begin{array}{l}\text { Temporary workers } \\
\text { (130 men, } 1,569 \text { person-years) }\end{array}$} & \multicolumn{2}{|c|}{$\begin{array}{l}\text { Unemployed } \\
\text { (41 men, } 459 \text { person-years) }\end{array}$} \\
\hline & $\mathrm{HR}(95 \% \mathrm{CI})$ & $\begin{array}{l}\% \text { reduction in } \\
\mathrm{HR}^{\mathrm{a}}\end{array}$ & $\mathrm{HR}(95 \% \mathrm{CI})$ & $\begin{array}{l}\% \text { reduction in } \\
\mathrm{HR}^{\mathrm{a}}\end{array}$ \\
\hline \multicolumn{5}{|l|}{ Mortality from all-causes } \\
\hline Adjusted for age and occupation & $2.21 *(1.16-4.24)$ & 100 & 4.09*** (1.85-9.01) & 100 \\
\hline Adjusted for age, occupation and health & $1.79(0.91-3.54)$ & 35 & $\mathbf{3 . 4 6}^{* *}(1.53-7.84)$ & 20 \\
\hline Adjusted for age, occupation, health, tobacco and alcohol & $1.71(0.86-3.40)$ & 41 & $\mathbf{3 . 5 6}^{* *}(1.59-7.95)$ & 17 \\
\hline \multicolumn{5}{|l|}{ Non-violent mortality } \\
\hline Adjusted for age and occupation & $2.22 *(1.12-4.40)$ & 100 & $\mathbf{3 . 8 7} * * *(1.66-9.03)$ & 100 \\
\hline Adjusted for age, occupation and health & $1.76(0.86-3.62)$ & 38 & $\mathbf{3 . 2 2} * *(1.34-7.75)$ & 23 \\
\hline Adjusted for age, occupation, health, tobacco and alcohol & $1.69(0.82-3.49)$ & 43 & $3.34 * *(1.40-7.94)$ & 18 \\
\hline \multicolumn{5}{|l|}{ Cancers } \\
\hline Adjusted for age and occupation ${ }^{\mathrm{b}}$ & $2.25(0.90-5.65)$ & 100 & $2.89(0.82-10.18)$ & 100 \\
\hline Adjusted for age, occupation and health & $1.79(0.68-4.72)$ & 37 & $2.38(0.65-8.75)$ & 27 \\
\hline Adjusted for age, occupation, health, tobacco and alcohol & $1.78(0.67-4.74)$ & 38 & $2.44(0.67-8.85)$ & 24 \\
\hline \multicolumn{5}{|l|}{ Cardiovascular diseases } \\
\hline Adjusted for age and occupation & 3.56* $(1.02-12.44)$ & 100 & $\mathbf{5 . 4 6}^{*}(1.07-27.84)$ & 100 \\
\hline Adjusted for age, occupation and health & $3.43(0.94-12.56)$ & 5 & $5.39 *(1.04-27.94)$ & 2 \\
\hline Adjusted for age, occupation, health, tobacco and alcohol & $3.46(0.95-12.67)$ & 4 & $\mathbf{5 . 5 4} *(1.08-28.51)$ & 0 \\
\hline
\end{tabular}

Significant estimates are in bold $* p<0.05 ; * * p<0.01 ; * * * p<0.001$

${ }^{\mathrm{a}}$ Reduction (\%) in HR computed with the following formula: $100 \times\left(\mathrm{HR}_{\text {age-occupation-adjusted }}-\mathrm{HR}_{\text {extended model }}\right) /\left(\mathrm{HR}_{\mathrm{age}-\mathrm{occupation} \text {-adjusted }}-1\right)$

b The age-occupation-adjusted HRs for temporary workers, and unemployed were close to significance $(p<0.10)$

that, within each occupational category, unemployed and the temporary workers are less educated than permanent workers. For instance, the proportion of male manual workers with primary education only is $38 \%$ among those with indefinite-term contracts, $51 \%$ among those with fixed-term contracts and $61 \%$ among the unemployed. This is in line with the segmentation theory, which states that there are differences in terms of skills between workers in the "core" and the "periphery" of the labour market (Gordon et al. 1982). A compositional difference of this type is a kind of indirect selection, which certainly contributes to the mortality disadvantage in the peripheral segments of the labour force.

In the literature, there is to our knowledge only one study, from Finland (Kivimäki et al. 2003), that has investigated mortality among temporary workers, over a 10-year observation period. In that study, the same type of gradient across the labour market core-periphery structure was found, and mortality was found to be 1.2-1.6 times higher among male and female temporary employees 
compared with permanent employees. More recently, a second analysis of the Finnish data showed that temporary workers were not a homogeneous group and that the mortality disadvantage was limited to those feeling that the insecure situation was unsatisfactory, and to those holding the job on an involuntary basis (Nätti et al. 2009). Indeed, temporary jobs are not all necessarily disadvantaged, and some may even be advantageous when they enable better control over the working time or are used as a stepping stone into permanent employment.

In a recent review and meta-analysis of unemployment and mortality (Roelfs et al. 2011), the mean hazard ratio for mortality was 1.63 among HRs adjusted for age and additional covariates. For the unemployed, we observed a larger gap (fourfold higher risk), but this should be related to the nature of the reference group, which in our study represents the core of the work force. Given the heterogeneity within the employed group, the traditional approach of using all employed as a reference, regardless of their type of employment, is bound to attenuate the association between unemployment and mortality.

In terms of causes of death, external causes, and particularly suicide, are at the forefront in the literature on unemployment and mortality (Mäki and Martikainen 2010). In the Finnish study (Kivimäki et al. 2003), temporary employment was associated among both men and women, with increased deaths from external causes and from alcohol-related causes and, in men only, from smoking-related cancers. Recently, Lundin et al. (2010) reported an increased risk of mortality for unemployed men from both natural and external causes. In line with these findings, among men we observed an association between temporary employment and unemployment at start of the study with non-violent mortality. Our hazard ratios for violent mortality were also very high among the unemployed, but, given the small number of deaths, significance was reached for women, but was borderline for men $(p<0.10)$.

For male temporary workers, we find evidence for a role of health, and, to a lesser extent, of tobacco and alcohol at baseline as explanatory factors for the excess mortality, more so for cancers than for cardiovascular diseases. This difference might be due to the fact that cardiovascular diseases are very much influenced by dietary habits, on which no information was collected in the survey. The role played by poor health in the disadvantage of temporary workers provides some support for the reverse causation (or selection) hypothesis, i.e. that the individuals with poor health are less likely to find a permanent job. On the other hand, the role of reverse causation needs to be mitigated, as health in this group of temporary workers may have been altered by cumulative exposures to hazardous working conditions, occupational injury or occupational diseases. In support of this interpretation, further analysis of the study data showed that the prevalence of self-reported functional limitations for daily living activities at baseline was $20 \%$ for permanent employment, $33 \%$ for temporary employment and $41 \%$ for unemployment among men $(p<0.001)$ and 14, 21 and $23 \%$, respectively, among women $(p<0.001)$.

For male unemployed, we find a lower contribution of poor health and behavioural factors than for male temporary workers (fully adjusted HR 3.6, $p<0.01,17 \%$ reduction in HR). This may suggest that the post-unemployment pathway plays a significant role for the unemployed. According to the "coping hypothesis", individuals cope with the stress associated with unemployment by changing their health behaviours in unhealthy ways (Hammarstrom and Janlert 1994). This change is already visible in our data. Further to this, some studies have demonstrated that the experience of joblessness has longterm effects on income [the "unemployment scar" (Arulampalam 2001)]. A "scar" of this type could contribute to less favourable pathways, particularly because "unemployment spells do not happen at random, but tend to take place as part of a generally disadvantaged life course"(Bartley and Ferrie 2010).

The health effects of different types of employment situations may differ by gender, and the idea that loss of employment may have less of a negative influence for women has been supported, with the argument that women are more able to cope because they take on roles as mothers and housewives. We found no significant mortality inequalities among women, although the hazard ratios associated with female unemployment were quite elevated. First, certain types of temporary jobs may have positive aspects for women whenever they need to invest more of their time and energy in family life. This might be changing, since women's traditional social roles are evolving, with working status becoming an increasingly important component of women's identity (Bambra 2010). Second, while women are more likely to belong to the more peripheral temporary workforce, they are less involved than men in manual jobs, which are the most exposed to occupational health risks. It is also worth noting that there were no significant differences across employment situations in terms of smoking and alcohol misuse among women and that the differences for poor health were much smaller than among men (Table 2). This finding is consistent with the greater contribution of unhealthy behaviours to the excess mortality of male temporary workers and definitely calls for targeted prevention approaches on these issues.

Before turning to policy implications, it is important to stress the study limitations. First, the response rate was rather moderate (about $44 \%$ ). However, this response rate 
is similar to those of other studies using postal selfadministered questionnaires in France (Goldberg et al. 2001). Furthermore, the distributions for gender, age, education, marital status, occupation, unemployment and occupational injury in the initial sample were close to those of the census population ("Appendix").

Second, given the small number of observations in the exposure groups (unemployed and temporarily employed), our study did not possess sufficient statistical power and used wide confidence intervals for the estimations. The main issue in this case is type II error rather than type I error, and therefore, the significant findings that we report are all the more unlikely to arise by chance. Another reassuring point is that our hazard ratio estimates for the unemployed agree with those found in a five-year mortality follow-up of the French longitudinal samples derived from the 1975, 1982 and 1990 censuses (3.9 for men and 1.9 for women in (Mesrine 2000)), compared to 4.1 and 2.7 (nonsignificant) in our study.

Third, our analyses are based on subjects' employment situation, health and behaviours at the start of the study, and we do not have retrospective information, nor do we have updates during the follow-up period. Not knowing to what extent poor health and unfavourable health behaviours are the cause or the consequence of remaining or becoming a temporary worker or unemployed, we cannot give credit to a causality relation and have therefore emphasized both causation and reverse causation (selection) hypotheses in the discussion. Given the sample size and the issues outlined above, our findings definitely need to be replicated and confirmed.

\section{Conclusion}

The issue of precarious employment and health is progressively gaining more visibility in the public health arena, but the empirical evidence is scant. Based on a unique mortality follow-up in a region of France subjected to economic hardship, our study uncovers large mortality inequalities and provides evidence for a new form of mortality inequality across the core-periphery structure of the labour market. The evolution of the Lorraine region during the past decades, from a prosperous industrial region to one of the most socioeconomically disadvantaged regions in the country, could partly explain the role of health behaviours as coping mechanisms for the population. Our findings have important policy implications, particularly in terms of prevention focused on unhealthy behaviours among male temporary workers and the unemployed.

Furthermore, job insecurity today is bound to lead to wider health consequences than in the economic recessions of the 1980s, given the progressive weakening of the protection of citizens against labour market risks by the welfare state in many countries (DeNavas-Walt et al. 2011; Observatoire des inégalités 2011). It follows that fuller consideration of the new forms of health inequalities in the flexible labour market landscape is required (Benach and Muntaner 2007).

Acknowledgments Lorhandicap study group: N. Chau, F. Guillemin, J.-F. Ravaud, J. Sanchez, S. Guillaume, J.P. Michaely, C. Otero Sierra, B. Legras, A. Dazord, M. Choquet, L. Méjean, N. TubianaRufi, J. P. Meyer, Y. Schléret and J. M. Mur. The authors would like to thank D. Saouag, M. Weiss, M. Depesme-Cuny and B. Phélut for their help during the survey. The work was supported by a Grant from the Pôle Européen de Santé.

Conflict of interest The authors declare that they have no conflict of interest.

\section{Appendix}

See Table 4.

Table 4 Comparison between the study sample and the general population (Lorraine region of the north-eastern France, Census 1999) $(\%)$

\begin{tabular}{|c|c|c|}
\hline & $\begin{array}{l}\text { Study } \\
\text { sample }\end{array}$ & $\begin{array}{l}\text { General } \\
\text { population }\end{array}$ \\
\hline Number of subjects & 6,200 & $1,893,826$ \\
\hline Women & 52.4 & 51.6 \\
\hline \multicolumn{3}{|l|}{ Age (years) } \\
\hline $15-19$ & 6.0 & 8.6 \\
\hline $20-24$ & 8.0 & 7.9 \\
\hline $25-29$ & 10.1 & 8.6 \\
\hline $30-49$ & 36.9 & 36.0 \\
\hline $50-59$ & 12.4 & 13.4 \\
\hline $60-74$ & 20.4 & 17.2 \\
\hline 75 or over & 6.2 & 8.3 \\
\hline \multicolumn{3}{|l|}{ Educational level } \\
\hline University & 16.9 & 22.0 \\
\hline High/middle school & 48.0 & 42.3 \\
\hline Primary school & 35.1 & 35.7 \\
\hline \multicolumn{3}{|l|}{ Marital status } \\
\hline Married and single $^{\mathrm{a}}$ & 88.7 & 86.0 \\
\hline Separated/divorced & 4.4 & 5.6 \\
\hline Widowed & 6.9 & 8.4 \\
\hline Retirees & 25.0 & 20.6 \\
\hline \multicolumn{3}{|l|}{ Working population } \\
\hline Number of subjects & 2,882 & 888,470 \\
\hline Job category & & \\
\hline
\end{tabular}


Table 4 continued

\begin{tabular}{lll}
\hline & $\begin{array}{l}\text { Study } \\
\text { sample }\end{array}$ & $\begin{array}{l}\text { General } \\
\text { population }\end{array}$ \\
\hline $\begin{array}{l}\text { Managers, professionals and associate } \\
\text { professionals }\end{array}$ & 32.0 & 32.2 \\
$\begin{array}{l}\text { Farmers, craftsmen, tradesmen, heads of firm } \\
\text { Service workers/clerks }\end{array}$ & 5.6 & 7.0 \\
$\quad$ Manual workers & 23.7 & 28.7 \\
$\begin{array}{l}\text { Unemployed among economically active } \\
\text { people }\end{array}$ & 38.7 & 32.1 \\
$\begin{array}{c}\text { Annual prevalence of occupational injury } \\
\text { with sick leave }\end{array}$ & 11.9 & 11.8 \\
\hline
\end{tabular}

Standardized mortality ratio (for 1996-2008 period): 0.91 vs. France, 0.86 vs. Lorraine region

Source: Institut National d'Etudes Démographiques, 1999. France métropolitaine-Enquête annuelle de recensement 1999

${ }^{\text {a }}$ We cannot separate married and single due to differences between our study (living as couple/married and single) and the Lorraine census (married and unmarried)

b We cannot separate these subgroups due to differences between our study and the Lorraine census

c Non-included in the 2,882 subjects

${ }^{\mathrm{d}}$ Concerns the general compensation system, which includes about the two-thirds of the working population in the Lorraine region (the prevalence was similar for France)

\section{References}

Arulampalam W (2001) Is unemployment really scarring? Effects of unemployment experiences on wages. Econ $\mathrm{J}$ 111(November):585-606

Bambra C (2010) Yesterday once more? Unemployment and health in the 21st century. J Epidemiol Commun Health 64:213-215

Banavides F, Benach J, Diez-Roux A, Roman C (2000) How do types of employment relate to health indicators? Findings from the second European survey on working conditions. J Epidemiol Commun Health 54:494-501

Bardasi E, Francesconi M (2004) The impact of atypical employment on individual well-being: evidence from a panel of British workers. Soc Sci Med 58:1671-1688

Bartley M, Ferrie J (2010) Do we need to worry about the health effects of unemployment? J Epidemiol Commun Health 64(1):5-6

Bartley M, Ferrie J, Montgomery SM (1999) Living in a highunemployment economy: understanding the health consequences. In: Marmot M, Wilkinson RG (eds) Social determinants of health. Oxford University Press, Oxford, pp 81-104

Baumann M et al (2007) Associations of social and material deprivation with tobacco, alcohol, and psychotropic drug use, and gender differentials: a population-based study. Int J Health Geogr 6:50-60

Benach J, Muntaner C (2007) Precarious employment and health: developing a research agenda. J Epidemiol Commun Health 61:276-277

Benach J, Benavides F, Platt S, Diez-Roux A, Muntaner C (2000) The health-damaging potential of new types of flexible employment: a challenge for public health researchers. Am J Public Health 90(8):1316-1317
Benach J, Amable M, Muntaner C, Benavides F (2002) The consequences of flexible work for health: are we looking at the right place? J Epidemiol Commun Health 56:405-406

Beresford T, Blow F, Hill E, Singer K, Lucey M (1990) Comparison of Cage questionnaire and computer-assisted laboratory profiles in screening for covert alcoholism. Lancet 336:482-485

Chau N, Choquet M, Lorhandicap group (2009) Relationship of job demands to initiating smoking in working people: a populationbased study. Ind Health 47:319-325

De Cuyper N, Kiran S, De Witte H, Aygoglu F (2008) Associations between temporary employment, alcohol dependence and cigarette smoking among Turkish health care workers. Econ Ind Democr 29:388

De Cuyper N, Notelaers G, De Witte H (2009) Transitioning between temporary and permanent employment: a two-wave study on the entrapment, the stepping stone and the selection hypothesis. J Occup Organ Psychol 82:67-88

DeNavas-Walt C, Proctor B, Smith J, U.S. Census Bureau, Current Population Reports (2011) Income, poverty and health insurance coverage in the United States: 2010. U.S. Government Printing Office, Washington, DC

Goldberg M et al (2001) Socioeconomic, demographic, occupational, and health factors associated with participation in a long-term epidemiologic survey: a prospective study of the French GAZEL cohort and its target population. Am J Epidemiol 154(4): 373-384

Gordon D, Edwards R, Reich M (1982) Segmented work, divided workers: the historical transformation of labor in the United States. Cambridge University Press, Cambridge

Hammarstrom A, Janlert U (1994) Unemployment and change of tobacco habits: a study of young-people from 16 to 21 years of age. Addiction 89(12):1691-1696

Iezzoni L, O’Day B (2006) More than ramps. A guide to improving health care quality and access for people with disabilities. Oxford University Press, Oxford

INSEE (2011) Tableaux de l'économie française. INSEE, Paris

Jung Y, Oh J, Huh S, Kawachi I (2013) The effects of employment conditions on smoking status and smoking intensity: the analysis of Korean Labor \& Income Panel 8th-10th wave. PLoS ONE 8(2):e57109

Junod B (2006) Le CDD un tremplin vers le CDI dans deux tiers des cas...mais pas pour tous. Paris: DARES, Document d'études No 117

Kivimäki M, Vahtera J, Virtanen M, Elovaino M, Pentti J, Ferrie J (2003) Temporary employment and risk of overall and causespecific mortality. Am J Epidemiol 158:663-668

Legleye S, Peretti-Watel P, Baumann M, Beck F, Chau N (2011) Gender and age disparities in the association of occupational factors with alcohol abuse and smoking in the French working people. Revue d'Epidémiologie et de Santé Publique 59: 223-232

Lemogne $C$ et al (2012) Gender differences in the association between depressive mood and mortality: a 12-year follow-up population-based study. J Affect Disord 136(3):267-275

Lundin A, Lundberg I, Hallsten L, Ottosson J, Hemmingsson T (2010) Unemployment and mortality-a longitudinal prospective study on selection and causation in 49321 Swedish middle-aged men. J Epidemiol Commun Health 64:22-28

Mäki N, Martikainen P (2010) A register-based study on excess suicide mortality among unemployed men and women during different levels of unemployment in Finland. J Epidemiol Commun Health. doi:10.1136/jech.2009.105908

Mesrine A (2000) La surmortalité des chômeurs: un effet catalyseur du chômage? Economie et Statistique 334(4):33-48

Nätti J, Kinnunen U, Mäkikangas A, Mauno S (2009) Type of employment relationship and mortality: prospective study among 
Finnish employed in 1984-2000. Eur J Pub Health 19(2):150-156

Observatoire des inégalités (2011) Une couverture santé à deux vitesses. In: http://www.inegalites.fr/spip.php?article1450

Petit H (2006) Generalised precariousness or persistent segmentation? In: Köhler C, Junge K, Schröder T, Struck O (eds) Trends in employment stability and labour market segmentation. Jena and Halle: Sonderforschungsbereich Gesellschaftliche Entwicklungen nach dem Systemumbruch - Diskontinuität, Tradition und Strukturbildung, pp 33-40

Quesnel-Vallée A, DeHaney S, Ciampi A (2010) Temporary work and depressive symptoms: a propensity score analysis. Soc Sci Med 70:1982-1987

Roelfs D, Shor E, Davidson K, Schwartz J (2011) Losing life and livelihood: a systematic review and meta-analysis of unemployment and all-cause mortality. Soc Sci Med 72:840-854

Thirion B, Schmitt A (2010) L'emploi en Lorraine: tertiarisation par désindustrialisation, forte poussée des femmes et des seniors. Economie Lorraine 207:1-6

van Beljouwe I, Verhaak P, Prins M, Cuijpers P, Penninx B, Bensing J (2010) Reasons and determinants for not receiving treatment for common mental disorders. Psychiatr Serv 61:250-257
Virtanen M, Kivimäki M, Elovainio M, Vahtera J (2002) Selection from fixed term to permanent employment: prospective study on health, job satisfaction, and behavioural risks. J Epidemiol Commun Health 56:693-699

Virtanen P, Liukkonen V, Vahtera J, Kivimäki M, Koskenvuo M (2003) Health inequalities in the workforce: the labour market core-periphery structure. Int J Epidemiol 32:1015-1021

Virtanen M, Kivimäki M, Joensuu M, Virtanen P, Elovainio M, Vahtera J (2005) Temporary employment and health: a review. Int J Epidemiol 34(3):610-622

Virtanen M et al (2006) Sickness absence as a risk factor for job termination, unemployment, and disability pension among temporary and permanent employees. Occup Environ Med 63:212-217

Waenerlund A, Gustafsson P, Virtanen P, Hammarström A (2011) Is the core-periphery labour market structure related to perceived health? Findings of the Northern Swedish Cohort. BMC Public Health 11:956 